\title{
Memadupadankan antara Kompetensi Konselor Aspek Asesmen BK dengan Pengembangan Literasi Siswa di Sekolah ${ }^{1}$
}

\author{
Catharina Tri Anni \\ catharina ta@mail.unnes.ac.id \\ Doktor Bimbingan dan Konseling \\ Fakultas Ilmu Pendidikan Universitas Negeri Semarang \\ Ninik Setyowani \\ niniksetyowani@mail.unnes.ac.id \\ Magister Bimbingan dan Konseling \\ Fakultas Ilmu Pendidikan Universitas Negeri Semarang \\ Kusnarto Kurniawan \\ kusnarto@mail.unnes.ac.id \\ Magister Bimbingan dan Konseling \\ Fakultas Ilmu Pendidikan Universitas Negeri Semarang
}

Integrating between Counselor Competencies Guidance and Counseling Assessment aspect into Student Literacy Development in School

\begin{abstract}
The global development of the 21st century demanding students ability to be more critical, analytical and creative, so the school have a role as an instrument to shape that personality. School literacy movement is one effort to answer the demands. Through literacy students are conditioned to intelligently analyze, construct mindsets, which ultimately generate critical and dignified behaviors in the deal with the times changing. Student behavior is formed through the conditioning of school environments involving multiple parties, including guidance and counseling teachers. The guidance and counseling teacher should be able to translate the needs of the students to develop literacy skills through programs designed for students. Guidance and counseling teachers are able to integrated student literacy development procedures in classroom learning with services provided to students, so that the development of this literacy is integrated with guidance and counseling services.
\end{abstract}

Keywords: assessment competence of counselor, literacy development

\footnotetext{
1 diajukan dalam seminar dan Lokakarya Nasional “ Peran Bimbingan dan Konseling pada Penguatan Pendidikan Karakter dan Literasi di Sekolah, 8-9 November 2017 di UKSW Salatiga
} 


\section{PENDAHULUAN}

Perubahan dunia global di abad 21 menuntut kemampuan masyarakat (siswa) harus bisa berpikir kritis, kemudian mampu melakukan analisis serta reflektif terhadap perubahan dunia. Terkait dengan tuntutan jaman tersebut, pemerintah sampai hari ini masih terus menerus melakukan Gerakan Literasi Sekolah (GLS), gerakan yang berupaya secara menyeluruh untuk menjadikan sekolah sebagai organisasi pembelajaran yang warganya literat sepanjang hayat melalui pelibatan publik. Literasi Sekolah dalam konteks GLS adalah kemampuan mengakses, memahami, dan menggunakan sesuatu secara cerdas melalui berbagai aktivitas, antara lain membaca, melihat, menyimak, menulis, dan/atau berbicara. Gerakan ini perlu dilakukan dengan tujuan menumbuhkembangkan budi pekerti peserta didik melalui pembudayaan ekosistem literasi sekolah yang diwujudkan dalam Gerakan Literasi Sekolah agar mereka menjadi pembelajar sepanjang hayat (Dirjenpendasdikbud, 2016).

Kegiatan literasi muncul sebagai bentuk mewujudkan proses pendidikan untuk mengembangkan kompetensi dan minat peserta didik terhadap pengetahuan, yang selama ini ketrampilan siswa masih rendah. Kegiatan ini ditujukan kepada guru dan tenaga kepustakaan supaya memfasilitasi siswa untuk bisa menjadikan mereka literat sepanjang masa.

Guru dalam hal ini guru BK mempunyai peran yang strategis untuk menumbuhkan budaya baca para siswanya, terutama melalui layanan BK yang dilakukan. Budaya literasi bisa ditumbuhkembangkan melalui program layanan yang dibuat guru BK. Penyusunan program BK terkait literasi ini diawali dengan asesmen yang dilakukan untuk mengungkap kebutuhan siswa. Melalui asesmen dapat diungkap kebutuhan siswa di bidang apa, entah bidang belajar, karir, sosial atau pribadi. Menilik macam literasi bisa berkaitan dengan numerik, bahasa, sains, budaya dan sebagainya. Bagaimana seorang guru BK memadukan antara macam literasi dengan jenis bimbingan melalui kebutuhan siswa. Tuntutan kondisi ini menuntut juga para guru BK untuk lebih banyak belajar untuk bisa menyinkronkan kebutuhan siswa dengan gerakan literasi nasional. Kegiatan BK menjadi bagian yang integral dengan kegiatan pendidikan. Kendala yang nampak bahwa seringkali para guru BK sendiri tidak mempunyai budaya baca, kondisi ini nampak pada guru BK yang stagnan pada keilmuan yang dulu dipelajari saat studi. Kondisi ini sering nampak tatkala guru BK harus melakukan penelitian tindakan bimbingan dan konseling mereka lemah karena budaya membacanya rendah. Seperti fenomena yang diperoleh pada saat melakukan kegiatan evaluasi pasca pelatihan analisis asemen, para guru BK terutama yang berasal dari luar jurusan BK mengeluh bahwa instrumen yang diajarkan masih bersifat teoritis dan bagaimana mereka membuat instrumen dengan prosedur yang harus dilalui, seperti menentukan indikator perilaku yang akan diukur masih bingung (Anni, 2017). Padahal kalau kita cermati bahwa untuk melakukan analisis instrumen dibutuhkan pengetahuan untuk membuat instrumen dengan syarat yang terstandar, seperti validitas, reliabilitas dan utilitasnya. Sementara itu hasil penelitian yang dipublikasikan dalam jurnal Educational Management ditemukan bahwa guru BK selama ini tatkala membuat instrumen tidak pernah diukur validitas, relibiltas dan utilitasnya (Anni, 2012: 101). Andai ada yang 
mencoba mengukur validitas reliabilitasnya mereka lakukan di antara mereka saja, sehingga belum memenuhi syarat keilmuannya. Seperti yang dikemukakan oleh Santohadi (2010: 124) bahwa melakukan need assesment yang bermutu harus didasarkan pada bukti ilmiah (evidence based assesment). Need assesment ini akan terbukti lebih konsisten, berarti, dan berguna dibandingkan asesmen tanpa melalui uji validasi. Seyogyanya guru BK atau konselor tatkala membuat instrumen dengan mengukur validitas, reliabilitas dan utilitas membutuhkan kerja sama dengan perguruan tinggi.

Fenomena lain terkait dengan budaya baca dari guru BK, tatkala penulis memberikan pelatihan tentang penelitian tindakan bimbingan dan konseling yang berhasil menulis hingga menghasilkan karya penelitian dan publikasi jurnal tidak lebih dari $40 \%$, menurut pengakuan mereka, karena tidak punya buku literateur, tidak memahami teori-teori yang melandasi tatakala melakukan penelitian (Hasil pengamatan dalam Pelatihan Peningkatan Kompetensi PTBK Guru SMA/SMK Provinsi Jawa Tengah, 2014-2016). Perilaku kontraproduktifnya, mereka tidak berusaha mencari toko buku untuk memenuhi kebutuhan kognitifnya, sehingga penyebab masalahnya bisa teratasi (Hasil wawancara saat Pelatihan Peningkatan Kompetensi PTBK Guru SMA/SMK Provinsi Jawa Tengah, 2014-2016).

Fenomena lain pada saat melatih guru menuju profesional, tatkala mereka dihadapkan pada teori-teori konseling (yang muatan teoritisnya sangat kuat) mengaku mengalami kesulitan untuk melakukan analisis kasus berdasarkan teori konseling yang relevan. Mereka mengaku sudah tidak ada waktu lagi untuk mengupdate ilmu yang harusnya mendukung kegiatan professionalnya, sehingga tatkala mengimplementasikan teori ke dalam kegiatan profesionalnya nampak kesulitan (Hasil Wawancara pada saat PLPG Guru Sekolah Menengah Provinsi Jawa Tengah secara Daring dan Tatap Muka, 2017)

Kompetensi guru BK terutama pada kompetensi asesmen BK menuntut guru BK untuk mampu memilih teknik asesmen, menyusun dan mengembangkan instrumen asesmen sesuai dengan kebutuhan pelayanan Bimbingan dan Konseling ( BSNP, 2009: 10), kompetensi tersebut mengisyaratkan bahwa guru BK harus mampu memilih dan menyusun instrumen untuk pengembangan kerja profesionalnya. Makna lebih dalam seorang guru BK untuk mampu seperti tuntutan dalam kompetensi tersebut harus mempunyai kemampuan literasi yang secara kontinyu untuk dikembangkan.

Merujuk fenomena di atas, bahwa untuk mengembangkan literasi siswa, maka guru $\mathrm{BK}$ juga harus memulai dari diri sendiri untuk mengembangkan kemampuan literasi yang terkait dengan kegiatan profesional yang akan dirancang untuk kegiatan para siswa. Permasalahan yang akan dibahas pada makalah konseptual ini terkait dengan bagaimana memadupadankan kompetensi asesmen guru BK dengan pengembangan literasi siswa di sekolah. Artinya kompetensi asesmen BK yang ditujukan untuk guru BK dapat dimanfaatkan untuk mengembangkan kemampuan literasi siswa di sekolah.

\section{KAJIAN TEORITIS}

\section{Ruang Lingkup Literasi}

Literasi dimaknai sebagai kemampuan siswa untuk melakukan 
kemampuan mengakses, memahami, dan menggunakan sesuatu secara cerdas melalui berbagai aktivitas, antara lain membaca, melihat, menyimak, menulis, dan/atau berbicara (Dirjenpendasdikbud, 2016: 2). Pemaknaan literasi tersebut mengundang pelibatan banyak pihak, baik sekolah, guru mata pelajaran, guru BK, stakeholder maupun orang tua. Pelibatan banyak pihak tidak akan berjalan dengan baik, manakala tidak ada struktur yang menjadi acuannya. Sekolah sebagai organisasi pembelajaran berfungsi menjadikan semua warganya terampil membaca untuk menjadikan siswa sebagai pembelajar sepanjang hayat. Antara lain yang bisa dilakukan sekolah membuat regulasi terkait penerapan pembiasaan pada semua warga sekolah, guru mata pelajaran bisa melakukan dalam proses pembelajaran dengan menerapkan berbagai metode inovatif, sedangkan guru BK harus mampu mengadaptasi materi layanan BK dengan metode yang inovatif, sehingga kegiatan layanan dapat menjadi instrumen untuk mengembangkan literasi siswa.

Gerakan Literasi ini mempunyai tujuan menumbuhkembangkan budaya literasi di sekolah untuk meningkatkan kapasitas warga dan lingkungan sekolah agar literat dan menjadikan sekolah sebagai taman belajar yang menyenangkan dan ramah anak; Sehingga warga sekolah mampu mengelola pengetahuan, supaya bisa menjaga keberlanjutan pembelajaran dengan menghadirkan beragam buku bacaan dan mewadahi berbagai strategi membaca (Ditjen Dikdasmen, 2016).

Tujuan tersebut mengundang berbagai pihak untuk mendukung perwujudannya, sehingga terdapat berbagai upaya yang bisa dilakukan, dengan memperhatikan berbagai langkah yang ada: 1) Langkah pembiasaan dengan cara penumbuhan minat baca melalui kegiatan 15 menit membaca (Permendikbud No. 23 Tahun 2015), 2) Langkah pengembangan dengan cara meningkatkan kemampuan literasi melalui kegiatan menanggapi buku pengayaan, dan 3) Langkah ke 3 pembelajaran, upaya yang dilakukan adalah meningkatkan kemampuan literasi di semua mata pelajaran: menggunakan buku pengayaan dan strategi membaca di semua mata pelajaran. Mencermati langkah yang dilakukan untuk menumbuhkan kemampuan literasi siswa, maka ada upaya yang dilakukan di luar kelas atau di luar pembelajaran, yaitu menumbuhkan minat membaca, pembiasaan ini bisa dilakukan pada saat siswa masuk ke lingkungan sekolah sudah dihadapkan pada poster berisi tulisantulisan terkait dengan kata-kata mutiara, kata mutiara tersebut diikuti dengan pemaknaannya. Tulisan tersebut tiap dua hari diganti dengan tulisan kata mutiara yang baru, harapannya kata mutiara dan maknanya sudah meresap di hati. Pada awal pembelajaran dibahas dengan cara siswa mengutarakan pendapatnya. Terus dilakukan secara berulang-ulang sampai menumbuhkan perilaku automacally pada siswa, perilaku automacally dapat dilihat dari indikasi bahwa siswa dapat menerapkan pemahaman tentang kata mutiara tersebut dalam perilaku seharihari. Pada langkah ke dua, guru bisa menugaskan siswa mencari buku cerita terkait dengan kata mutiara tersebut, kemudian mereka diminta membaca dan mempresentasikan di depan kelas. Komunikasi di kelas dibangun bahwa semua komentar yang dikemukakan siswa tidak ada yang salah, sehingga siswa akan termotivasi bisa menemukan mutiara nilai, sikap dan perilaku melalui cerita tersebut. Selanjutnya di langkah ke tiga guru bisa mengkaitkan topik bahasan 
dengan kata mutiara tersebut dalam pembelajaran. Proses ini dikondisikan setiap kali pembelajaran, sehingga siswa akan memperoleh perilaku literasi melalui hidden curriculum yang dibuat dalam pembelajaran.

\section{Cakupan Kompetensi dalam Profesi Guru BK atau Konselor}

Seorang guru BK atau konselor dituntut untuk dapat memenuhi kinerjanya sesuai dengan tuntutan dalam PP No.19 Tahun 2005 dan Undang-Undang Guru dan Dosen No.14 tahun 2005 menyatakan bahwa guru yang profesional harus mempunyai kompetensi profesional, pedagogik, kepribadian dan sosial. Kompetensi profesional merupakan kemampuan penguasaan materi layanan yang terkait dengan konsep ke BK an secara luas dan mendalam yang memungkinkan untuk membimbing peserta didik memenuhi standar kompetensi yang ditetapkan dalam standar nasional. Kompetensi tersebut harus didukung dengan kompetensi lain, yaitu paedagogis, artinya seorang guru BK atau konselor harus memiliki kemampuan untuk mengelola layanan BK, memahami karakteristik peserta didik, mampu mengembangkan strategi dalam layanannya, bahkan harus mampu melakukan evaluasi terhadap kegiatan yang sudah dilaksanakan. Sehingga kompetensi tersebut dapat mengembangkan potensi siswa sampai mencapai aktualisasi dirinya. Kedua kompetensi tersebut masih perlu didukung dengan kompetensi kepribadian, kompetensi ini menuntut guru $\mathrm{BK}$ atau Konselor memiliki performansi sebagai seorang guru BK atau konselor sesuai dengan tuntutan perilaku profesional. Seorang profesional selain memiliki kemampuan teknis dalam melaksanakan tugasnya, memiliki kemampuan berkaitan dengan keilmuan yang akan ditekuni, didukung kualitas pribadi yang dituntut dalam etika profesi dan kemampuan berkomunikasi tatkala melakukan tugas profesinya. Salah satu kompetensi yang dituntut dalam kompetensi tersebut adalah untuk mampu memilih teknik asesmen, menyusun dan mengembangkan instrumen asesmen sesuai dengan kebutuhan pelayanan Bimbingan dan Konseling (BSNP, 2009: 10). Kompetensi ini menuntut guru BK untuk bisa memilih teknik asesmen yang sesuai dengan kebutuhan siswa tatkala akan melakukan asesmen kebutuhan, di samping juga bisa menyusun dan mengembangkan instrumen manakala tidak tersedia instrumen yang sudah baku. Kemampuan memilih dan menyusun instrumen asesmen sangat terkait dengan kemampuan literasi guru BK dalam bidang pengetahuan asesmen. Seringkali guru BK kurang tepat dalam memilih instrumen, karena kurang banyak membaca. Budaya membaca pada guru BK bisa diterapkan bersamaan dengan pengkondisian diterapkan untuk siswa, namun materialnya yang berbeda. Sebagai contoh: di ruang $\mathrm{BK}$ hendaknya dibuat perpustakaan kecil yang berisi buku ke BK an dan perkembangan remaja atau materi sejenis terkait dengan remaja. Perpustakaan tersebut memiliki dwifungsi, yang pertama bagi guru BK atau konselor perpustakaan tersebut dapat mendukung guru BK atau konselor untuk mengembangkan kemampuan literasinya, sehingga kemampuan literasi guru BK akan mendukung kerja profesinya. Ke dua bagi siswa, perpustakaan tersebut akan menjadi sumber informasi yang tepat, dengan membaca siswa akan memperoleh pengetahuan yang lebih luas dari materi di luar mata pelajaran. Pembiasaan ini seperti yang diharapkan oleh pemerintah melalui GLS, bahwa "kegiatan 15 menit membaca buku 
nonpelajaran sebelum waktu belajar dimulai" (Dirjen Pendasmen Kemendikbud, 2016: 1). Kegiatan ini dilaksanakan untuk menumbuhkan minat baca peserta didik serta meningkatkan keterampilan membaca agar pengetahuan dapat dikuasai secara lebih baik. Bentuk pembiasan ini bisa disinkronkan dengan kebutuhan siswa melalui asesmen yang dilakukan oleh guru BK atau konselor.

\section{Padupadan Asesmen BK dengan Pengembangan Kemampuan Literasi Siswa}

Kompetensi asesmen BK mempunyai manfaat untuk memetakan kebutuhan siswa dalam kerangka menyusun program BK. Bertolak dari asesmen BK, guru BK atau Konselor mampu merumuskan kebutuhan siswa yang terkait dengan pengembangan literasi siswa yang tertuang pada kegiatan layanan BK. Sebagai contoh dalam layanan bidang karir, guru BK atau konselor harus mampu memilih materi bacaan yang dapat mendukung pengembangan karir dan kemampuan literasi siswa. Proses guru BK atau konselor memilih materi bacaan sudah mengkondisikan guru BK atau konselor membaca, sehingga dengan tuntutan kompetensinya tersebut akan mengembangkan kemampuan literasinya. Pelaksanaan layanan BK yang sekaligus akan mengembangkan literasi siswa dapat melibatkan banyak pihak, seperti stakeholder, kepala sekolah, orang tua, guru mata pelajaran. Di bawah ini akan dijelaskan langkah-langkah kegiatan layanan yang akan diintegrasikan/ dipadupadankan dengan pengembangan literasi siswa. Layanan BK yang akan diberikan di bidang karir dengan melibatkan stakeholder dan warga sekolah.

Tahapan pengembangan layanan BK dengan kemampuan literasi siswa, meliputi Tahap ke 1 Pembiasaan Pembiasaan kegiatan membaca yang menyenangkan di ekosistem sekolah, Tahap ke 2 Pengembangan minat baca untuk mengembangkan kemampuan literasi dan Tahap ke 3 Pelaksanaan pembelajaran berbasis literasi (Dirjen Pendasmendikbud, 2016: 28).

Tabel 1 Perbandingan Tahapan Literasi dan Tahapan Kegiatan Layanan BK

\begin{tabular}{|c|c|c|c|}
\hline \multicolumn{2}{|r|}{ Tahapan Literasi } & \multicolumn{2}{|c|}{ Tahapan Layanan Bimbingan Klasikal } \\
\hline Tahap & Kegiatan & Tahap & Kegiatan \\
\hline Pembiasaan & $\begin{array}{l}\text { 1. Lima belas menit membaca setiap } \\
\text { hari sebelum jam pelajaran } \\
\text { melalui kegiatan membacakan } \\
\text { buku dengan nyaring (read aloud) } \\
\text { atau seluruh warga sekolah } \\
\text { membaca dalam hati (sustained } \\
\text { silent reading). } \\
\text { 2. Membangun lingkungan fisik } \\
\text { sekolah yang kaya literasi }\end{array}$ & Pembukaan & $\begin{array}{l}\text { 1. Guru BK atau konselor menyapa } \\
\text { siswa dengan kalimat yang } \\
\text { membuat siswa bersemangat. } \\
\text { 2. Pada tahap ini diikuti dengan } \\
\text { proses Ice Breaking/ games } \\
\text { sederhana. } \\
\text { 3. Guru BK atau konselor } \\
\text { menyampaikan tujuan umum } \\
\text { dan tujuan khusus yang akan } \\
\text { dicapai } \\
\text { 4. Guru BK atau konselor } \\
\text { menanyakan kesiapan siswa } \\
\text { mengikuti layanan }\end{array}$ \\
\hline $\begin{array}{l}\text { Pengem- } \\
\text { bangan }\end{array}$ & $\begin{array}{l}\text { 1. Lima belas menit membaca setiap } \\
\text { hari sebelum jam pelajaran } \\
\text { melalui kegiatan membacakan } \\
\text { buku dengan nyaring, membaca } \\
\text { dalam hati } \\
\text { 2. Mengembangkan lingkungan }\end{array}$ & Inti & $\begin{array}{l}\text { 1. Peserta didik melakukan } \\
\text { berbagai kegiatan sesuai } \\
\text { langkah-langkah dan tugas serta } \\
\text { tangggung jawab yang } \\
\text { telah dijelaskan } \\
\text { 2. Guru Bimbingan dan Konseling }\end{array}$ \\
\hline
\end{tabular}




\begin{tabular}{|c|c|c|c|}
\hline \multicolumn{2}{|r|}{ Tahapan Literasi } & \multicolumn{2}{|c|}{ Tahapan Layanan Bimbingan Klasikal } \\
\hline Tahap & Kegiatan & Tahap & Kegiatan \\
\hline & $\begin{array}{l}\text { fisik, sosial, afektif sekolah yang } \\
\text { kaya literasi dan menciptakan } \\
\text { ekosistem sekolah } \\
\text { 3. Pengembangan kemampuan } \\
\begin{array}{l}\text { literasi melalui kegiatan di } \\
\text { perpustakaan sekolah/ } \\
\text { perpustakaan kota/daerah }\end{array}\end{array}$ & & $\begin{array}{l}\text { atau konselor memberikan } \\
\text { materi yang telah disiapkan }\end{array}$ \\
\hline Pembelajaran & $\begin{array}{l}\text { 1. Lima belas menit membaca setiap } \\
\text { hari sebelum jam pelajaran } \\
\text { melalui kegiatan membacakan } \\
\text { buku dengan nyaring } \\
\text { 2. Kegiatan literasi dalam } \\
\text { pembelajaran, disesuaikan dengan } \\
\text { tagihan akademik di kurikulum } \\
\text { 2013 } \\
\text { 3. Menggunakan lingkungan fisik, } \\
\text { sosial afektif, dan akademik } \\
\text { disertai beragam bacaan }\end{array}$ & Penutup & $\begin{array}{l}\text { 1. Guru Bimbingan dan Konseling } \\
\text { atau konselor memberikan } \\
\text { penguatan atau } \\
\text { merencanakan tindak lanjut. }\end{array}$ \\
\hline
\end{tabular}

Berikut implementasi layanan BK yang terintegrasi dengan pengem-bangan kemampuan literasi siswa seperti tertera di tabel berikut.

Tabel 2. Padupadan Tahapan Literasi dengan Pelaksanaan Layanan BK

\begin{tabular}{|c|c|}
\hline Tahapan & Kegiatan \\
\hline Pembukaan /pembiasaan & $\begin{array}{l}\text { 1. Guru BK memberi salam dan menyampaik tujuan layanan } \\
\text { 2. Guru BK meminta siswa untuk membaca buku tentang "Tokoh-tokoh } \\
\text { sukses dalam karir" (pertemuan sebelumnya guru sudah meminta } \\
\text { membaca buku tersebut yang bisa diakses melalui internet atau di } \\
\text { perpustakaan sekolah) }\end{array}$ \\
\hline Inti/ Pengembangan & $\begin{array}{l}\text { 1. Siswa diminta untuk mempresentasikan hasil bacaan terkait dengan } \\
\text { tokoh sukses dalam karir } \\
\text { 2. Siswa memberikan komentar atas presentasi tersebut dengan } \\
\text { pengetahuan siap yang dimiliki } \\
\text { 3. Siswa diminta menulis refleksi dari hasil bacaan dan diskusi di kelas } \\
\text { 4. Siswa diminta membaca buku lagi/ bisa akses internet terkait macam- } \\
\text { macam jabatan dan persyaratan karir } \\
\text { 5. Siswa diminta memperdalam bacaan terkait dengan karir yang diminati } \\
\text { 6. Siswa diminta membuat map karir yang menjadi cita-citanya }\end{array}$ \\
\hline Penutup /Pembelajaran & $\begin{array}{l}\text { 1. Guru memberikan penguat terhadap materi yang telah dibahas tadi } \\
\text { 2. Tugas berikut di rumah siswa diminta mencari komparasi jabatan karir } \\
\text { yang dipilih dengan jabatan karir teman untuk diperdalam melalui buku } \\
\text { bacaan lain } \\
\text { ( misal cita-citaku jadi guru, cita-cita teman sebelah jadi pengusaha. Si } \\
\text { siswa diminta membaca untuk memperdalam jabatan terkait pengusaha } \\
\text { seperti apa. } \\
\text { 3. Guru BK mengakhiri layanan dengan memotivasi siswa untuk selalu } \\
\text { membaca dari tugas berikutnya. }\end{array}$ \\
\hline
\end{tabular}

\section{Berdasarkan bahasan tentang} pelaksa-naan layanan BK yang dapat digunakan untuk mengembangkan kemampuan literasi siswa, dengan cara meminta siswa pada tahap awal untuk membaca materi terkait dengan topik bimbingan yang akan diberikan di kelas. Hasil bacaan tersebut diminta untuk 
mempresentasikan dan merefleksikan melalui tugas map karir pilihanya. Di bagian akhir layananpun siswa masih diminta untuk memperdalam materi karir teman lain, yang outputnya siswa dapat membuat map karir dirinya dan satu temannya yang akan di tempel ke papan bimbingan yang sudah disediakan oleh guru BK di depan ruang BK. Melalui papan bimbingan tersebut, siswa akan terkondisi selalu membaca berbagai hal untuk pengembangan potensi dirinya. Dengan pengondisian tersebut, diharap-kan sekolah terutama kegiatan BK akan terbangun ekosistem yang literat seperti kondisi yang memungkinkan pengem-bangan sikap kritis, kreatif, inovatif, berjiwa wirausaha, perilaku empati sosial, dan cinta kepada pengetahuan (Dirjenpendasmendikbud, 2016: 44).

\section{PEMBAHASAN}

Pembentukan kemampuan literasi pada siswa bukanlah sesuatu yang mudah, karena kemampuan literasi merupakan kemampuan untuk menjadi-kan waga sekolah meningkat literasinya sepanjang hayat. Menurut Wandasari (dalam JMKS,2017: 325) menyatakan bahwa prestasi literasi membaca peserta didik di Indonesia masih rendah, berada di bawah rata-rata skor internasional. Dari laporan hasil studi yang dilakukan Central Connecticut State University di New Britain, diperoleh informasi bahwa kemampuan literasi Indonesia berada pada peringkat 60 dari 61 negara yang disurvei. Kondisi kemampuan literasi siswa seperti disebutkan di atas menggelitik pemerintah untuk menyusun strategi menuju ke peningkatan kemampuan literasi tersebut. Maka pemerintah mengupayakan melalui gerakan literasi sekolah dengan pembiasaan menumbuhkan minat membaca setiap hari selama 15 menit dengan bacaan yang menarik atau di luar buku pelajaran.

Buku bacaan yang menarik merupakan stimulus yang akan menumbuhkan reaksi siswa untuk membaca dengan senang. Penelitian yang dilakukan oleh Wulandari (2017: 328) menyatakan bahwa implementasi gerakan literasi sekolah ini didukung oleh potensi guru, orangtua dan sekolah. Faktor pendukung berupa tersedianya sarana untuk mensosialisasikan kebijakan, hibah buku dari orangtua, waktu dan dana, guruguru yang mempunyai semangat belajar, mahasiswa PPL juga membantu dalam pelaksanaan program-program perpustakaan, serta semua warga sekolah terlibat aktif dalam program yang dibuat sekolah. Senada dengan hasil penelitian tersebut, maka sekolah harus berusaha secara kreatif untuk menyediakan buku bacaan yang menarik dan relevan dengan perkembangan siswa di jaman Now. Hasil penelitian yang sama menyatakan bahwa buku yang kaya akan nilai serta gambar-gambar menarik sulit didapatkan di Indonesia. Buku bacaan yang kaya nilai dan gambar yang menarik merupakan salah satu bentuk stimulus seperti yang dinyatakan dalam teori Behavioristik Pavlov bahwa perilaku manusia akan terbentuk melalui pembiasaan atau pengkondisian secara terus menerus stimulus respon (Rifai dan Anni, 2016). Hubungan stimulus respon akan meningkat manakala ada varian dalam stimulus, maka akan meningkatkan kualitas respon. Oleh karena itu stimulus yang dilakukan untuk meningkatkan respon harus bervariasi, sehingga stimulus untuk meningkatkan kemampuan literasi 
siswa hendaknya tidak cukup hanya berupa buku bacaan yang menarik saja, namun diperlukan stimulus lain, seperti bentuk poster yang berisi motivasi, kata-kata bijak, kata-kata mutiara dalam bentuk banner atau digital. Melalui pengkondisian secara terus menerus pesan yang telah disampaikan akan meresap ke dalam pikiran siswa dan diharapkan akan menggerakan siswa dalam perilaku seharihari. Kemudian perubahan perilaku tersebut tidak akan semakin meningkat manakala sekolah tidak memberikan reinforcement terhadap perubahan perilaku tersebut. Bentuk reinforcement dapat dilakukan dalam kegiatan sekolah atau di luar sekolah, sebagai contoh sekolah secara periodik melakukan kompetisi terkait dengan performa literasi tersebut, seperti kompetisi bercerita secara smart, bangun komunikasi dengan membaca dan sebagainya. Kompetisi tersebut sebagai instrumen untuk memperkuat minat siswa dalam membaca, apalagi siswa yang meraih kejuaraan mendapat reward edukatif, maka minat literasi tersebut akan terus tumbuh dan berkembang. Peningkatan kemampuan literasi siswa harus secara terus menerus dilakukan, karena kemampuan literasi akan mendukung proses belajar siswa di sekolah, seperti yang dinyatakan oleh the Australian Institute for Teaching and School Leadership (AITSL) bahwa kemampuan literasi yang tinggi sangat penting untuk proses pendidikan siswa. Kemampuan literasi juga dibutuhkan pada saat siswa belajar di universitas, kemudian "melaksanakan tuntutan intelektual pengajaran" (AITSL, 2014)

Kondisi seperti itu hendaknya dipadukan dengan kegiatan layanan BK, yang bermuara pada penyusunan program untuk memenuhi kebutuhan siswa. Guru BK hendaknya dapat melakukan layanan yang bersifat perseveratif terhadap kondisi yang sudah dibentuk oleh sekolah, seperti mengoptimalkan papan bimbingan sebagai media pembiasaan siswa membaca untuk memperoleh informasi terkait dengan perkembangan diri siswa hingga mencapai yang optimal. Kemampuan literasi dapat meningkat sebagai suatu budaya bukanlah hanya sekedar berhenti pada gerakan yang tidak keberlanjuatan. Terkait dengan peran penting guru BK untuk mengembangkan kemampuan literasi siswa, maka guru BK pun harus mengembangkan kemampuan literasinya. Hasil penelitian Moon (2014: 112) menyatakan bahwa guru sekolah menengah hendaknya memiliki tiga kompetensi literasi, yaitu literasi profesional, literasi paedagogi umum dan literasi paedagogi yang didasarkan pada disiplin ilmu. Literasi profesional dimaksudkan bahwa guru dapat mengakses dan menyajikan informasi dalam berbagai bentuk, memahami apa yang mereka baca, mengkomunikasikan ide dengan jelas kepada kolega dan masyarakat, memelihara catatan yang jelas dan akurat, mempublikasikan karya mereka dalam bentuk profesional yang diterima, mempertahankan komunikasi dalam hubungan kolegial. Literasi paedagogi umum, maknanya guru dapat manifestasikan kemampuan guru untuk mengajarkan keterampilan keaksaraan yang kompleks, seperti penulisan esai dan kutipan bibliografi. Kemampuan literasi paedagogis lebih berkaitan langsung dengan kemampuan guru untuk mendorong standar literasi yang tinggi pada siswa-siswanya Literasi yang berbasis disiplin keilmuan, 
dimaknai sebagai kapasitas untuk menghubungkan isi kurikuler dengan bentuk-bentuk bahasa dan literasi yang terkait dengan disiplin tertentu. Guru mampu menggunakan bahasa dalam caracara khusus untuk mengkodifikasi dan mengkomunikasikan pengetahuan yang ia ajarkan. Mengajarkan bahasa dan bentukbentuk literasi terkait, merupakan bagian integral dengan mengajar subjek itu sendiri. Oleh karena itu seorang guru sekolah menengah yang efektif harus memiliki pengetahuan yang cukup tentang bahasa untuk mengajarkan konten tersebut.

Ke tiga kompetensi literasi yang dikemukakan oleh Moon hendaknya juga bisa diterapkan oleh guru BK. Pengembangan literasi profesional, hendaknya guru BK dapat menuangkan gagasannya dengan baik, kreatif seperti saat merumuskan topik layanan sebagai manifestasi dari kebutuhan siswa. Kemampuan literasi ini akan menjadi daya tarik bagi siswa tatkala mengikuti layanan di kelas. Selanjutnya literasi paedagogik umum, hendaknya guru BK dapat memanfaatkan metode dalam modelmodel pembelajaran cooperative learning untuk dimanfaatkan tatkala melakukan layanan klasikal. Sehingga guru BK akan lebih kreatif dan tepat menggunakan metode pembelajaran untuk mencapai tujuan dalam layanan. Pengembangan literasi berbasis displin kelimuan. Pada kemampuan ini guru BK bisa membahasakan pengetahuan yang dimiliki saat memberikan layanan, seperti saat melakukan layanan konseling individu atau kelompok, guru BK dapat menerapkan teknik-teknik konseling dengan menggunakan bahasa yang mudah dipahami oleh siswa.

\section{PENUTUP}

Kemampuan literasi merupakan kemampuan yang tidak begitu saja dapat berujud, namun kemampuan untuk bisa berpikir cerdas tatkala menghadapi perkembangan digital membutuhkan suatu proses yang panjang. Oleh karena itu proses penkondisian seperti dalam teori Behavioristik sangatlah sesuai diterapkan untuk pembentukan kemampuan tersebut. Melalui kemampuan literasi ini siswa akan terbentuk budipekertinya melalui pembudayaan ekosistem literasi sekolah untuk menjadi pembelajar sepanjang hayat.

Pembentukan kemampuan literasi ini terkait dengan kompetensi guru BK atau konselor tatkala melakukan asesmen kebutuhan siswa. Kegiatan asesmen kebutuhan tersebut dapat digunakan untuk memetakan kebutuhan siswa, dan guru BK harus mampu memadupadankan kebutuhan siswa dengan pengembangan literasinya. Salah satu upaya yang dapat dilakukan guru BK dengan memadukan tahapan pengembangan literasi dengan tahapan dalam melaksanakan layanan BK, yaitu dari tahap pembiasaan, pengembangan dan pembelajaran. Tahapan-tahapan tersebut dapat dipadupadankan ke dalam tahapan layanan BK, seperti kegiatan pada tahap awal atau pembukaan yang dilakukan dalam layanan BK dipadukan dalam tahap pembiasaan, sehingga akan ada proses pembiasaan perilaku dengan landasan ke BKan. Begitu seterusnya pada dua tahap berikutnya, yaitu tahapa kegiatan inti dan tahap kegiatan penutup. Pengkondisian ini yang akan membentuk kemampuan literasi siswa untuk menjadi literan sepanjang hayat. Kelak akan berdampak pada pembentukan budi pekerti peserta didik melalui 
pembudayaan ekosistem literasi sekolah yang diwujudkan dalam Gerakan Literasi Sekolah agar mereka menjadi pembelajar sepanjang hayat.

\section{DAFTAR PUSTAKA}

Anni, C.T. 2017. Laporan Pengabdian pada Masyarakat. Semarang: Tidak Dipublikasikan

-------. 2012. Need Assesment Model Penyusunan Program Bimbingan dan Konseling Bidang Bimbingan Belajar Berbantuan Sistem Informasi Manajemen Di SMA Negeri Kota Semarang. Jurnal Educational Management. Vol I(1). Hal.101

-------. 2014-2016. Hasil Pengamatan dalam Pelatihan Peningkatan Kompetensi PTBK Guru SMA/SMK Provinsi Jawa Tengah

-------. 2014-2016. Hasil wawancara saat Pelatihan Peningkatan Kompetensi PTBK Guru SMA/SMK Provinsi Jawa Tengah.

-------. 2017. Hasil Wawancara pada saat PLPG secara Daring dan Tatap Muka Guru Sekolah Menengah Provinsi Jawa Tengah

BNSP. 2009. Permenas RI Nomer 27 Tahun 2008 Tentang Standar Kualifikasi Akademik dan Kompetensi Konselor. Jakarta: -

Ditjen GTK kemendikbud. 2016. Panduan Operasional Pelaksanaan Bimbingan dan Konseling. Jakarta: -

Ditjen Dikdasmen Kemendikbud.tt. Buku Saku Gerakan Literasi Sekolah. Jakarta: -

-------. 2016. Panduan Gerakan Literasi Sekolah Di Sekolah Menengah Atas. Jakarta: -
------, 2016. Disain Induk Gerakan Literasi Sekolah. Jakarta: -

Moon, B. 2014. The Literacy Skills of Secondary Teaching Undergraduates: Results of Diagnostic Testing and a Discussion of Findings. Australian Journal of Teacher Education, 39(12). 8. Page 111-130 diunduh pada tanggal 20 Mei 2018 di http://ro.ecu.edu.au/ajte/ vol39/iss 12/8

Rifai dan Anni. 2016. Psikologi Pendidikan. Semarang: MKDK UNNES Press

Santoadi, F. 2010.Manajemen Bimbingan dan Konseling Komprehensif. Yogyakarta: Universitas Sanata Dharma

Wandasari, Y. Implementasi Gerakan Literasi Sekolah (Gls) Sebagai Pembentuk Pendidikan Berkarakter. Jurnal Manajemen, Kepemimpinan, dan Supervisi Pendidikan. $(J M K S)$.Volume 1, No. 1, JuliDesember 2017. Hal.325-343 